\title{
Canadian Pulp and Paper in World Trade
}

\author{
D. B. Cooke ${ }^{1}$
}

\begin{abstract}
Canada still commands a major position in two key world pulp and paper products which come from our softwood forest resource - newsprint and woodpulp. In 1977 Canada produced $40 \%$ of the newsprint and $30 \%$ of the softwood bleached kraft used in the free world. Fine papers, linerboard and tissue grades of paper are made chiefly for the domestic market and are all tariff protected.

After 30 years of excellent growth, the future prospects for the Canadian pulp and paper industry are clouded by: slower world demand for paper and board, increased selfsufficiency for newsprint and pulp in many of Canada's key markets, continuing trends to substitution of cheaper pulp fibres for the more expensive softwood bleached kraft pulp, the cornerstone of Canada's pulp industry.
\end{abstract}

\section{Position of Canada's Paper Industry in the Free World}

First, very quickly let's place our industry into the world picture ${ }^{2}$ by looking at the $1972-74$ period which saw the high-water mark for pulp and paper (Table 1). (For most products we have yet to see 1974 levels reached again.)

\section{Newsprint}

Newsprint, one of Canada's major forest products, is freely traded and historically this sector has grown enormously because of our proximity to a large market, plentiful wood, water, energy and skilled labor at competitive costs. This year, of roughly 8 million metric tons which Canada will produce

$71 \%$ will go to the U.S.

$10 \%$ to Canadian publishers/printers

$19 \%$ to overseas markets.

Overseas markets which are expected to take 1.5 million tonnes this year include:

\begin{tabular}{|c|c|}
\hline & Tonnes \\
\hline U.K. . . . . . . & 460,000 \\
\hline Other Europe.$\ldots \ldots \ldots \ldots \ldots \ldots \ldots$ & 160,000 \\
\hline Latin America . . . . . . . . . . . . . . . . . . & 540,000 \\
\hline 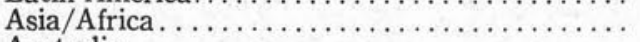 & 280,000 \\
\hline 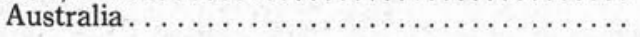 & 80,000 \\
\hline
\end{tabular}

2 All world figures exclude centrally planned countries.

1 Director of Market Research and Economics, MacMillan Bloedel Ltd., Vancouver. Paper presented to Working Group 9, Economics and Policy, Canadian Institute of Forestry, October 5, 1977, Vancouver, B.C.
Now these tonnages are very close to shipments in 1974 which was a historical high.

As far as our traditional markets are concerned for newsprint there are no tariff problems or what we might call trade restrictions which would limit our opportunities, other than the basic changes that we foresee for the longer term. (I will discuss these later.)

\section{Printing and Writing Papers}

Let us look next at printing and writing. (This is the other part of the so-called "cultural papers" group and is sometimes referred to as fine papers.) Canada is not a large producer in world terms. The United States is - but largely for its own consumption. The reason this group is not a major factor in world trade is because of the diversity of products, the general tendency to make the grades on smaller machines within markets and tariff barriers. This group is a major user of wood pulps (one of Canada's chief export items).

There is, however, a trend in the printing and writing sector to high-production units and the development of commodity-type grades (magazine papers, computer print-out paper, etc.) which will be amenable to export and increasing world trade. Canada is an exporter of certain wood-containing grades as an off-shoot of newsprint production. However, there could be an opportunity for the manufacture of the higher grades of fine papers if we can economically produce and sell in a very competitive market which has a large, well established, fine paper industry - the U.S. Tariff barriers are an additional hurdle and, more significantly as far as other markets are concerned, there is the current move to self-sufficiency in cultural papers in many of the developing countries.

\section{Packaging and Tissue Grades}

The third major paper and paperboard group, classified as "Other Paper and Paperboard", includes the packaging grades which make up the bulk of this category. Such grades as linerboard, boxboard, bag paper, would be included here. You can see again how the U.S. dominates world production and consumption. This category is the large waste paper user and (except for the smaller tissue sector) it is not a major user of market pulps. Most pulps in this group are made and used on an integrated basis. 
Table 1. Free World Consumption of Paper \& Paper Board (1972-1974)

\begin{tabular}{|c|c|c|c|c|}
\hline$y$ & Million & & \% From & $\%$ From \\
\hline & Metric Tons & \multirow{4}{*}{$\begin{array}{l}\text { Produces } \\
\text { Uses } \\
\text { Produces \& } \\
\text { Uses } \\
\text { Produces } \\
\text { Uses }\end{array}$} & Canadian Mills & U.S. Mills \\
\hline 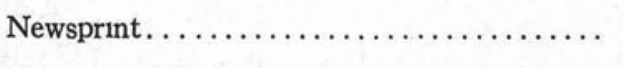 & 20.5 & & $\begin{array}{l}41 \% \\
4 \%\end{array}$ & $\begin{array}{l}15 \% \\
47 \%\end{array}$ \\
\hline Printing \& Writing . . . . . . . . . . . . . . $\ldots$ & 28.5 & & $3 \%$ & $40 \%$ \\
\hline Other ${ }^{\mathrm{a}} \ldots \ldots \ldots \ldots \ldots \ldots \ldots \ldots \ldots \ldots \ldots \ldots \ldots \ldots$ & 80.0 & & $\begin{array}{l}4 \% \\
3.5 \%\end{array}$ & $46.5 \%$ \\
\hline
\end{tabular}

a Chiefly Packaging.

As far as Canada is concerned we produce tissue grades for domestic consumption only (tissues are not easily exportable because of bulk). Boxboard grades for packaging (largely waste based) are highly localized. The only major grade in this large group which can be considered a tradeable item is linerboard which together with corrugating medium make up the corrugated container - a major user of fibre in the developed world.

Linerboard, however, requires low cost raw material and the economy of scale available to large integrated producing units. Canada is a marginal supplier. The U.S. South dominates the world industry: of 17 million tonnes produced in the free world, 12 million tonnes or almost $70 \%$ is made in the U.S.

Tariffs on linerboard are also a fact of life. Even the U.K., which at one time was duty-free to Canadian board and is still one of our key export markets, no longer provides tariff preference to Canada, but will be doing so for the Scandinavians.

\section{Japanese Self-Sufficiency}

Before I move into pulp, a major Canadian export item, I would like to say something about Japan. As the second largest economy of the western world, Japan accounts for some 15 million tonnes of paper and paperboard production or $12 \%$ of the western world's production. The pulp industry of Japan is almost entirely self-sufficient - in spite of a serious lack of raw materials $(41.5 \%$ of pulpwood is imported largely in the form of chips), Japan, the largest user of newsprint outside of the United States (2.4 million tonnes), produces slightly more than it consumes. At present, there is little opportunity for imports. Linerboard, the other major paper grade widely traded in world markets, is in almost the same category. Japan produces and uses about $1 \frac{1}{2}$ million tonnes and imports very little.

Paper pulps, on the other hand, are a major import item. Slightly under $9 \%$ of Japan's 10 million tonne pulp consumption is imported. Here is where B.C. and other suppliers enter the picture.

\section{Canada - A Major Supplier of Woodpulp to the Free World}

Turning to pulps, the western world consumption by grades has been as follows:

\begin{tabular}{|c|c|}
\hline - & $\begin{array}{l}\text { 1972-74 Avg. } \\
\text { Consumption }\end{array}$ \\
\hline $\begin{array}{l}\text { Mechanical \& Semi-Chemical.............. } \\
\text { Unbleached Sulphate...... } \\
\text { White Chemical Pulps } \quad \text { - Sulphite........ } \\
\end{array}$ & $\begin{array}{c}\text { MM Tonnes } \\
29.3 \\
27.2 \\
9.8 \\
29.7\end{array}$ \\
\hline $\begin{array}{l}\text { Waste. } \ldots \ldots \ldots \ldots \ldots \ldots \ldots \ldots \ldots \ldots \ldots \ldots \ldots \\
\text { Non-Wood. } \\
\text { Fillers. } \ldots \ldots \ldots \ldots \ldots \ldots \ldots \ldots \ldots \ldots \ldots\end{array}$ & $\begin{array}{r}33.5 \\
3.2 \\
6.0\end{array}$ \\
\hline Total $\ldots \ldots \ldots \ldots \ldots \ldots \ldots \ldots \ldots \ldots \ldots \ldots$ & 138.8 \\
\hline
\end{tabular}

About $28 \%$ of the chemical pulps are market pulps (i.e. where the pulps are dried and shipped to paper mills). It is the category that is important to Canada.

Again placing Canada in perspective, as far as white chemical pulps are concerned (the principal grades that are traded as market pulps), we produce $20 \%$ of the western world chemical pulps or 8 million tonnes. Of this almost $60 \%$ is exported.

If we examine softwood bleached kraft (Canada's primary grade), we have a $30 \%$ share of the world supply or over 5 million tonnes out of $171 / 2$ million tonnes, of which $3 \frac{1}{2}$ to 4 million tonnes are exported; Canada is the major exporter of this important product - about twice as much as the Nordic countries export.

In summary, Canada exports chiefly newsprint, linerboard, groundwood printings, and market pulps - chiefly, softwood bleached kraft. These are the major pulp and paper commodities traded throughout the world and with pulpwood chips and waste paper make up the bulk of fibre moved internationally. (I might say parenthetically that chips traded around the world account for some 4 to 5 million tonnes of pulp - 4 million tonnes in Japan alone.)

\section{Principal Canadian Pulp and Paper Markets}

\section{Canada's markets are:}

\section{For Newsprint}

United States: 5.6 million tonnes (the chief competition comes from the U.S. mills).

Canada: 0.8 million tonnes.

Overseas: 1.5 million tonnes (competition comes from Scandinavian and other suppliers such as New Zealand, Japan, Chile, South Africa, United States and, to an increasing degree, indigenous supply within markets that have been major im- 
porters, such as Mexico, Turkey, Nigeria, Peru, Argentina).

\section{For Linerboard}

Canada: 0.7 million tonnes.

Overseas: 0.35 million tonnes.

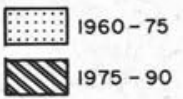

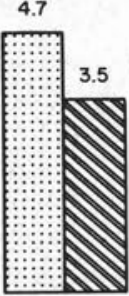
PAPERBOARD
TOTAL PAPER
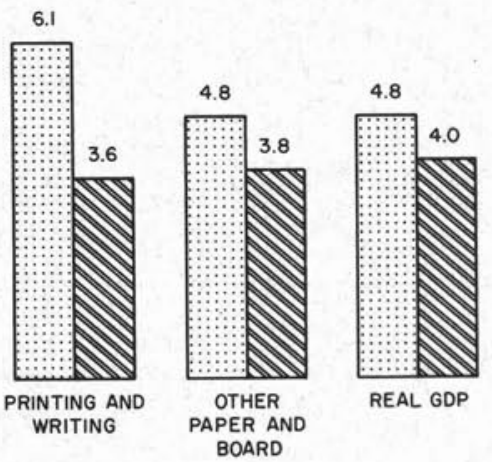

REAL GDP

Fig. 1. World paper and paperboard consumption average annual growth (per cent).

$1960-75$

NNN 1975-90

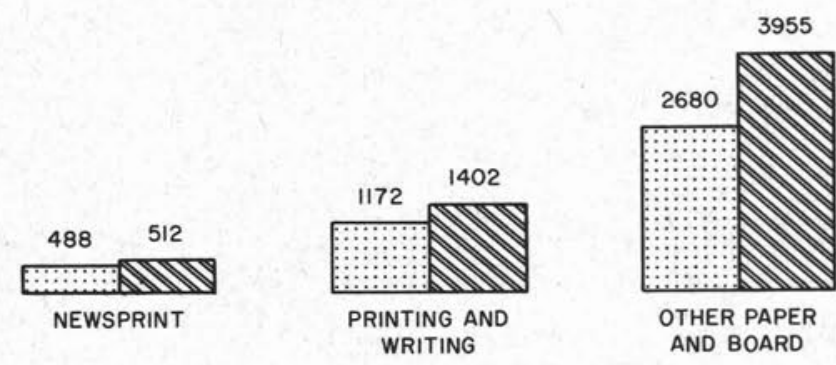

Fig. 2. World paper and paperboard consumption average annual growth (000 tonnes).

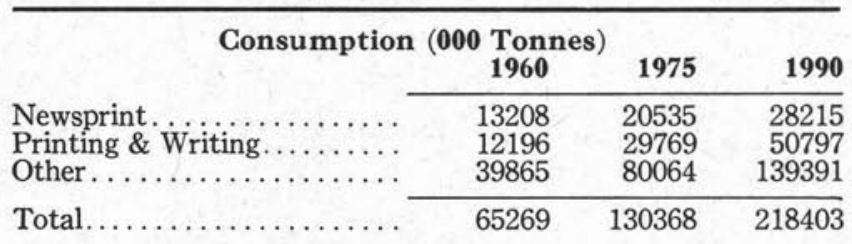

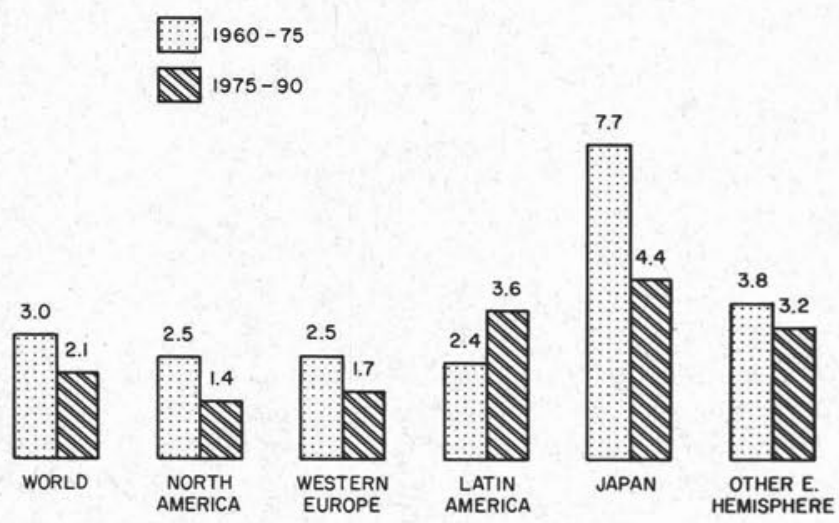

Fig. 3. Newsprint consumption average annual growth (percent).
The largest consumer, the U.S., is also the world's largest and lowest cost producer. It does not use Canadian linerboard.

In overseas markets, competition comes largely from the U.S. and in Europe from the U.S. and the Scandinavians.

Waste-based grades also compete, particularly in Western Europe. Japan has been largely a closed situation for linerboard imports although there are signs of some crack in the wall because of the need to increase imports in order to help balance the huge export surplus.

\section{For Groundwood Printings}

In the case of groundwood printing (part of the printing and writing group), Canada is increasing its production and exports of these grades, partly as a result of upgrading of older newsprint facilities and partly because of an increased use of lower cost printing papers as substitutes for the more expensive grades which use chemical pulps. Canadian markets for these products include the U.S. with a smaller amount to overseas areas (a good example here is telephone directory paper). (Tariffs for these grades in certain countries are at relatively low rates.)

\section{Bleached Kraft Pulp}

A semi-finished product but nevertheless with significant value added, bleached kraft pulp is, next to newsprint, our largest export grade of pulp and paper. It will continue to be a major item for us because it lends itself to economical transportation to world users, it is not as energy-intensive (external source) as newsprint. It has a great variety of uses and is ideally suited to blending with cheaper fibres. Our markets will continue to be the U.S., Western Europe and Japan. However, there will be increasing competition from producers in other countries and other fibre sources.

\section{Future Prospects for the Canadian Pulp and Paper Industry}

Now let us look to the 1980's. There are a number of fundamental factors that are affecting and will continue to affect the picture for our pulp and paper industry. They give us little comfort.

\section{Slower Demand Growth}

First, the growth rate in world demand has slowed. Figure 1 shows actual and projected free world growth rates in percentage terms - comparing $1960-75$ to $1975-90$. Figure 2 shows the growth rates in annual tonnage increments.

These charts were developed from a recentlycompleted FAO sponsored study. The slower growth is due partly to lower economic growth rates in the developed economies and partly to lower end-use consumption factors. (For example, in newsprint, lower basis weight of paper, lower usage due to electronic substitution.) Indeed, sub- 
209

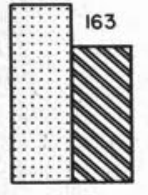

NORTH AMERICA

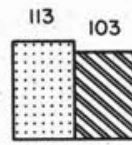

WESTERN EUROPE

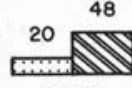

LATIN AMERICA

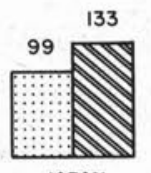

JAPAN
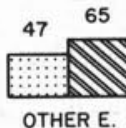

HEMISPHERE
Fig. 4. Newsprint consumption average annual growth $(000$ tonnes).

\section{Consumption -000 Tonnes}

\begin{tabular}{|c|c|c|c|}
\hline & 1960 & 1975 & 1990 \\
\hline 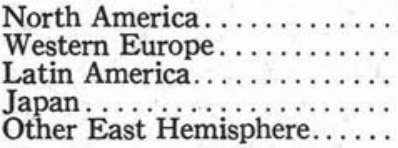 & $\begin{array}{r}7046 \\
3785 \\
720 \\
723 \\
934\end{array}$ & $\begin{array}{r}10179 \\
5482 \\
1022 \\
2215 \\
1637\end{array}$ & $\begin{array}{r}12627 \\
7032 \\
1737 \\
4212 \\
2607\end{array}$ \\
\hline World. & 13208 & 20535 & 821 \\
\hline
\end{tabular}

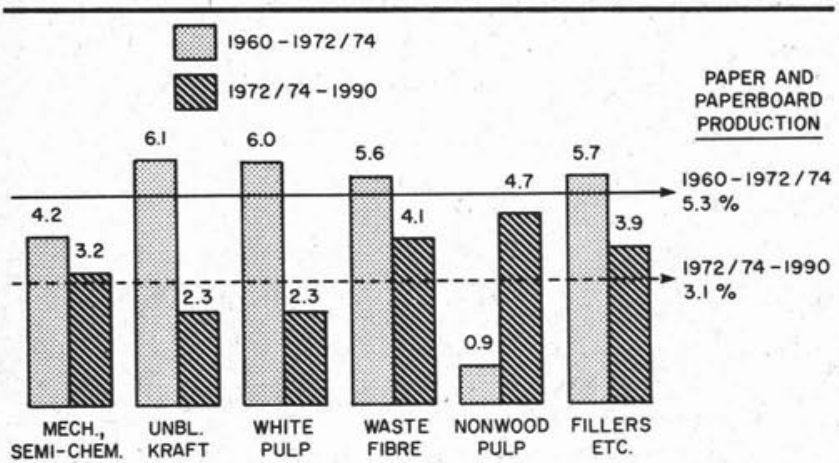

Fig. 5. World furnish requirements for paper and paperboard production average annual growth (per cent).

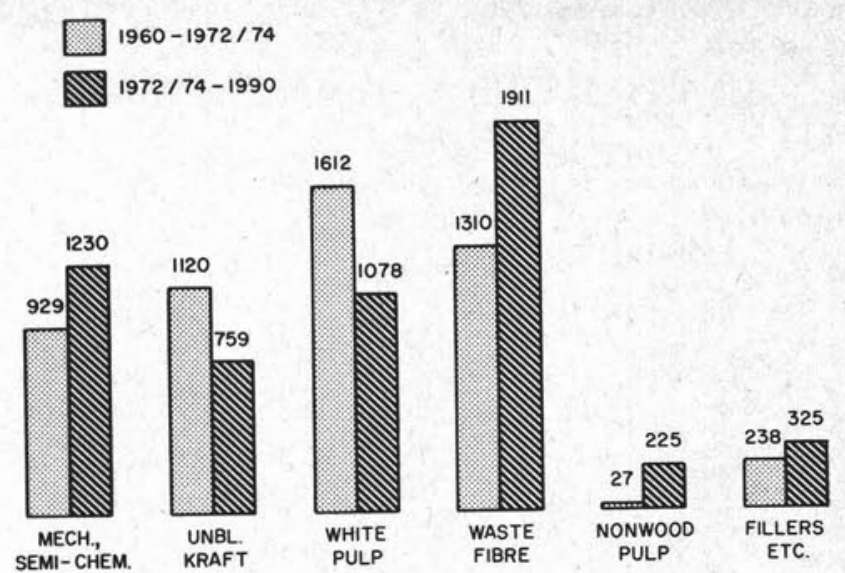

Fig. 6. World furnish requirements for paper and paperboard production average annual growth (000 tonnes).
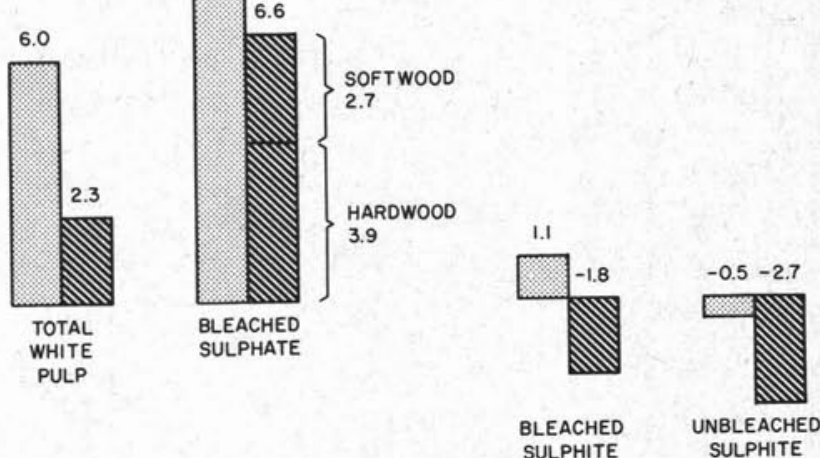

Fig. 7. White pulp consumption average annual growth (per cent).

Table 2. Bleached Softwood Sulphate Pulp Production \& Trade '000 Tonnes

\begin{tabular}{|c|c|c|c|c|c|c|}
\hline 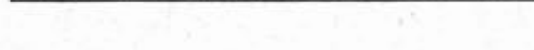 & \multicolumn{2}{|c|}{$1972-74$} & \multicolumn{2}{|c|}{1980} & \multicolumn{2}{|c|}{1990} \\
\hline & Prod. & Trade & Prod. & Trade & Prod. & Tra de \\
\hline 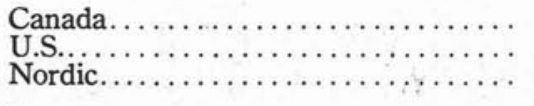 & $\begin{array}{l}4990 \\
8016 \\
2956\end{array}$ & $\begin{array}{r}-3737 \\
1675 \\
-1856\end{array}$ & $\begin{array}{l}5767 \\
9168 \\
3999\end{array}$ & $\begin{array}{r}-4401 \\
1650 \\
-2407\end{array}$ & $\begin{array}{r}7469 \\
10821 \\
5170 \\
\end{array}$ & $\begin{array}{r}-5679 \\
2135 \\
-3218\end{array}$ \\
\hline 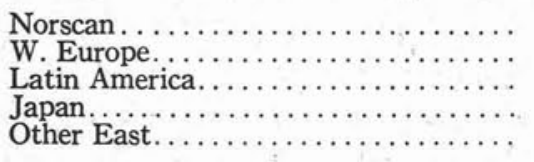 & $\begin{array}{r}15962 \\
492 \\
219 \\
457 \\
185\end{array}$ & $\begin{array}{r}-3918 \\
3089 \\
298 \\
539 \\
217\end{array}$ & $\begin{array}{r}18934 \\
660 \\
500 \\
540 \\
375\end{array}$ & $\begin{array}{r}-5158 \\
3735 \\
205 \\
653 \\
565\end{array}$ & $\begin{array}{r}23640 \\
1320 \\
1200 \\
670 \\
975\end{array}$ & $\begin{array}{r}-6762 \\
4870 \\
-\quad 172 \\
1279 \\
785\end{array}$ \\
\hline Total $\ldots \ldots \ldots \ldots \ldots \ldots \ldots \ldots$ & 17315 & 225 & 21131 & - & 27535 & 一 \\
\hline
\end{tabular}

stitution is likely to be a key phenomenon, not only between grades, but between paper and other substrates for packaging or other media for communicating, or other fibres for virgin chemical pulps.

\section{Increasing National Self-Sufficiency in Newsprint}

Second, of major significance to Canada is the increase in self-sufficiency in newsprint in the
U.S. and certain other traditional Canadian markets. The FAO study suggests that this trend will continue. As Figures 3 and 4 show, newsprint consumption will continue to grow both in per cent growth rate terms and tonnage terms, albeit at lower rates than in the past. However, Canada's market share will decline unless the self-sufficiency trend can be slowed through a more competitive Canadian stance. In fact, the FAO study says that Canada's free world market share for newsprint will drop to $33 \%$ in 1990 from $42 \%$ in 1972-1974. 
$1960-1972 / 74$

$1972 / 74-1990$
1579

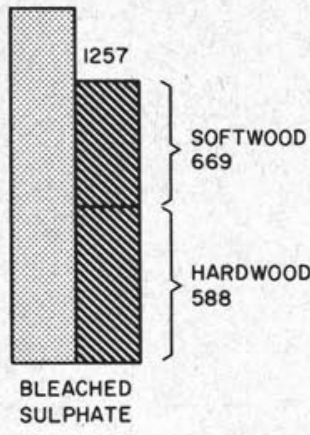

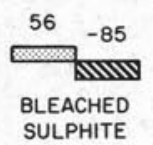

Fig. 8. White pulp consumption average annual growth (000 tonnes). $\begin{array}{ll}-24 & -94\end{array}$

साIV

UNBLEACHED SULPHITE

\begin{tabular}{|c|c|c|c|}
\hline \multicolumn{4}{|c|}{ Consumption } \\
\hline$\therefore$ & 1960 & $1972 / 74$ & 1990 \\
\hline $\begin{array}{l}\text { B1. Sulphate (HWD) } \ldots \ldots \ldots \\
\text { Bl. Sulphate (SWD) } \ldots \ldots \ldots\end{array}$ & - & $\begin{array}{l}12210 \\
17540\end{array}$ & $\begin{array}{l}23590 \\
27535\end{array}$ \\
\hline $\begin{array}{l}\text { Bl. Sulphate } \ldots \ldots \ldots \ldots \ldots \ldots \\
\text { Bl. Sulphite } \ldots \ldots \ldots \ldots \ldots \ldots \\
\text { Unbl. Sulphite } \ldots \ldots \ldots \ldots \ldots\end{array}$ & $\begin{array}{l}9217 \\
4726 \\
4647\end{array}$ & $\begin{array}{r}29750 \\
5458 \\
4340\end{array}$ & $\begin{array}{r}51125 \\
4009 \\
2732\end{array}$ \\
\hline Total White Pulp.......... & 18590 & 39548 & 57866 \\
\hline
\end{tabular}

\section{Substitution of Cheaper Fibres for Canadian Softwood Pulps}

Third, when we examine the future of our second largest export grade - softwood bleached kraft pulp - the problem of slower growth due to slower growth in paper demand is further magnified by substitution of cheaper fibres for softwood kraft (Figures 5-8). These include:

Waste Papers

Hardwood Pulps

In addition, as in the case of newsprint, we will see an increase in pulp self-sufficiency in market areas that traditionally have not been large pulp producers. Brazil and certain African countries are showing the greatest growth rates, particularly in hardwood grades which will, of course, compete with Canada's softwood.

\section{Growth of Canadian Pulp Exports}

If we examine the white pulp forecasts (Table 2), we can still see good growth for softwood bleached kraft $(570,000$ tonnes annually). While this growth will not be supplied entirely by Canada, we will continue to be the major exporter of this grade.

The FAO study shows Canadian exports of bleached softwood kraft increasing from 3.7 million tonnes in 1972-74 to 5.7 millions tonnes by 1990. The U.S. will still be our largest market (from 1.7 MM tonnes to $2.1 \mathrm{MM}$ tonnes). Western Europe - up slightly to $1 \frac{1}{2} \mathrm{MM}$ tonne level. Japan from $1 / 2 \mathrm{MM}$ to $1.3 \mathrm{MM}$.

Finally, a comment on the international aspect of pulp and paper and the vulnerability of the Canadian industry to decisions made by national governments or by our international competitors. I could list several important "events" that have impacted on us and in some cases will continue to affect our relative competitiveness.

- Energy cost increase.

- Currency devaluations.

- Swedish/Finnish government decision to support inventory accumulation in 1975/76.

- "Rationalization" of the European industry.

- Tariff changes - EFTA and EEC.

- Growth of investment in LDC's - plantations (Brazil, Africa, etc.).

- Increased international movement of chips.

- Government incentives.

It is these external and, in many cases, politically inspired events that we must consider carefully when contemplating investment in our industry in Canada. 